\title{
CORRESPONDENCE
}

\section{Growth and Puberty in German Children: Is There Still a Positive Secular Trend?}

by PD Dr. med. Bettina Gohlke, PD Dr. med. Joachim F. Woelfle in volume $23 / 2009$
3. Melnik BC: Permanent impairment of insulin resistance from pregnancy to adulthood: the primary basic risk factor of chronic Western diseases. Medical Hypotheses 2009; [pic]doi:10.1016/j.mehy.2009.04.047

4. Gohlke B, Wölfle J: Growth and puberty in German children: Is there still a positive secular trend? Dtsch Arztebl Int 2009; 106(23): 377-82.

Prof. Dr. med. Bodo Melnik

Universität Osnabrück, Sedanstr. 115, 49090 0snabrück, Germany melnik@t-online.de

\section{Consumption of Milk as a Vital Factor in Growth Development}

Longitudinal growth in German children has accelerated and final height increased since the mid-19th century. As possible causes of this "secular trend," the authors discuss socioeconomic status, genetic factors of the somatotropic axis, growth hormone, and insulinlike growth factor-1 (IGF-1), as well as nutritional and epigenetic factors. They conclude that especially factors of early childhood diet and epigenetic regulation of specific target genes explain this secular trend. Unfortunately, their review article does not include any mention of cow's milk and the way in which it vitally contributes to longitudinal growth. Numerous studies have shown that longitudinal growth correlates significantly with consumption of milk (1). Consumption of milk has an insulinotropic effect and, in contrast to meat, in children it raises serum concentrations of insulin and IGF-1, as well as increasing insulin resistance. Increased consumption of cow's milk during pregnancy is associated with higher birth weight and a larger size and is thus a possible risk factor of fetal macrosomia. Compared with breastfed infants, infants fed with cow's milk protein have higher postprandial insulin concentrations and IGF-1 serum levels. Consumption of cow's milk shifts the somatotropic axis to an unphysiologically high range (2). Since insulin and IGF-1 materially modify the promoter function of many genes, this explains the presumed epigenetic changes that accelerate longitudinal growth. The shift of the growth hormone-IGF-1 axis and its possible "misprogramming" in early childhood as a result of increased peripartal and postpartal consumption of cow's milk is suspected of increasing an existing predisposition for disorders with increased insulin resistance and raised IGF-1 concentrations, such as acne, obesity, diabetes mellitus, metabolic syndrome, cardiovascular disorders, and cancer (3). From a preventive medical perspective, this secular trend is of utmost importance. The milk induced shift of the somatotropic axis with induction of partial insulin resistance and resultant long term health effects should be subject to thorough further studies $(2,3)$

DOl: 10.3238/arztebl.2009.0656a

\section{REFERENCES}

1. Hoppe C, Molgaard C, Michaelsen KF: Cow's milk and linear growth in industrialized and developing countries. Ann Rev Nutr 2006; 26: 131-73.

2. Melnik BC: Milk - the promoter of chronic Western diseases. Med Hypotheses 2009; 72: 631-9.

\section{In Reply:}

The correspondent mentions a possible influence of cow's milk consumption in early childhood on longitudinal growth. As outlined in our paragraph on nutrition, an association between protein and calcium intake and the secular trend of longitudinal growth has been discussed earlier (1). However, such an association between nutritive factors and the secular trend in body height has been assumed not only for a diet rich in cow's milk but also for other food components, such as essential fatty acids and amino acids, vitamins, etc (2). The proposed mechanisms for how cow's milk might influence longitudinal growth in early childhood are interesting but remain vastly speculative. Although animal experiments have suggested that the quantity and quality of early childhood nutrition may influence the expression of components of the growth hormone-IGF-1 axis in the long term, this modulation of the axis can also be explained with an isolated influence on the quantities of food of breastfed animals (3). A monocausal explanation of the phenomenon that is the secular trend of longitudinal growth, by means of specific nutritional components such as the extent of cow's milk intake, is thus likely to be too reductionist. To sum up, there are many factors - both newly identified and well known — that may have a role in the secular change in longitudinal growth. For most of the suggested candidates, however, the question remains unanswered as to how and in which way they may be causally associated with the secular trend in longitudinal growth.

D0l: 10.3238/arztebl.2009.0656b

\section{REFERENCES}

1. Gohlke B, Wölfle J: Growth and puberty in German children: Is there still a positive secular trend? Dtsch Arztebl Int 2009; 106(23): 377-82.

2. Allen \& Uauy: Guidelines for the study of mechanisms involved in the prevention or reversal of linear growth retardation in developing countries. European Journal of Clinical Nutrition 1994: 48, Suppl. 1, 212-6.

3. Kappeler L, De Magalhaes Filho $\mathrm{C}$ et al.: Early postnatal nutrition determines somatotropic function in mice. Endocrinology 2009; 150(1): 314-23

\section{PD Dr. med. Joachim Wölfle}

Pädiatrische Endokrinologie und Diabetologie,

Universitätskinderklinik Bonn

Adenauerallee 119, 53113 Bonn, Germany

\section{Conflict of interest statement}

The authors of both contributions declare that no conflict of interest exists according to the Guidelines of the International Committee of Medical Journal Editors. 